
\title{
Knowledge
}

Talent is not a rare commodity-people are talented in many

ways: it is simply rarely released. To make talent happen organizations must give it strategic and holistic attention.

\section{A Primer on Talent Management}

\section{By Olivier Serrat}

\section{The Genesis of Talent Management}

Globalization, the process by which economies, societies, and cultures are fast integrating through a globe-spanning network of communication and trade, drives both collaboration and competition. And so, in an age when those who possess knowledge 1 —not land, labor, or capital goods — own the new means of production, it is no surprise that a contest for talent has been raging since the 1990 s. Better talent separates highperformance organizations from the rest. They bet on people, not strategies.

Critical talent is scarce (and about to become scarcer)

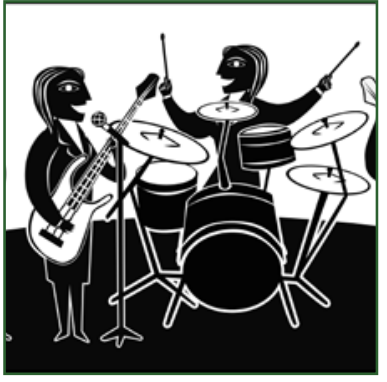
because of three trends: the ongoing retirement of the "Baby Boom Generation", 2 a widening skills gap, ${ }^{3}$ and large-scale social integration ${ }^{4}$ (driving rapidly changing lifestyles).

Talent management has become one of the most pressing topics in organizations (even if very few have strategies and operational programs in place with which to identify, recruit, develop, deploy, and retain the best). The competition for talent will define organizational milieus for a couple of decades to come. Springing from the three trends, several drivers

In the information era, the value of hard assets has declined compared with the value of an organization's intangible assets, e.g., reputation, name recognition, and intellectual property such as knowledge and knowhow. Human capital, also known as talent, is the primary source of the intangible assets in organizations today.

The "Baby Boom Generation" is a term that portrays those born in Asia, Australia, Europe, and North America after the Second World War, essentially between 1946 and 1955. They are now 55-64 years of age.

A skills gap is a discrepancy between an organization's current capabilities and the human capital it needs to achieve its goals. It is the point at which an organization may no longer grow or remain competitive because it cannot fill critical jobs with personnel that has the right knowledge, skills, and abilities.

The large-scale social integration that constitutes modernity involves (i) faster movement of information, capital, goods, and people among formerly discrete populations, and consequent influence beyond the local area; (ii) sharper specialization of the segments of society, e.g., division of labor; and (iii) tighter formal social organization of mobile populations, development of circuits and networks on which they and their influence travel, and societal standardization conducive to socioeconomic mobility. 
fuel the emphasis:

- Workforce demographics are evolving. ${ }^{5}$

- The context in which organizations conduct their operations is increasingly complex and dynamic. ${ }^{6}$

- More efficient capital markets have enabled the rise of small and medium-sized organizations that offer opportunities few large organizations can match, exerting a pull across the talent spectrum.

- In knowledge economies, talent is a rapidly increasing source of value creation.

- A demonstrated correlation between talent and organizational performance exists: talented individuals drive a disproportionate share of organizational effectiveness. (Value creation extends beyond individual performance differentials.)

- Financial markets and boards of directors demand more.

- The mobility of personnel ${ }^{7}$ is quickening on a par with changing expectations. ${ }^{8}$ If talent is hard to find, it is becoming harder to keep.

In 1997, McKinsey and Company studied 77 large organizations from various industries to circumscribe the magnitude of the war for talent. They talked to the top 200 executives in each company to appreciate why these executives worked where they did and how they had become the professionals they were. Organizations with winning employee value propositions had a compelling answer to the question, "Why would a talented person want to work here?' To create such a proposition, a great organization tailors its brand and productsthat is, the jobs it has to offer- to appeal. It also pays the price it takes to recruit and retain talented people. The overall top 200 population cared deeply about values and culture, freedom and autonomy, challenging jobs, and good management. Differentiation was important to their compensation and lifestyle. In sum, their rewards were psychological, developmental, and financial. In 1973, Peter Drucker wrote: "Making a living is no longer

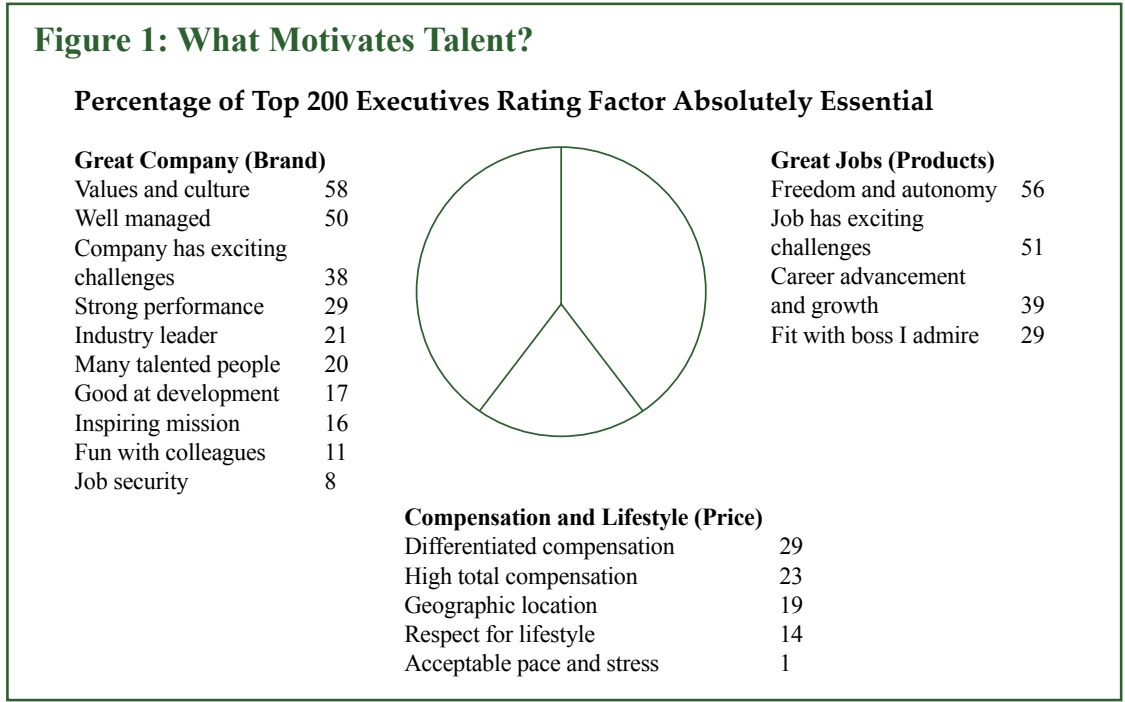

Source: Elizabeth Chambers, Mark Foulon, Helen Handfield-Jones, Steven Hankin, and Edward Michaels. 1998. The War for Talent. McKinsey Quarterly. No. 3.

5 For example, on top of the ongoing retirement of the "Baby Boom Generation" and certainly in the West, women are no longer joining the workforce en masse, white-collar productivity improvements have peaked, executives are not extending their careers, and immigration levels are stable (but might decline).

6 Knowledge economies call for people with global acumen, multicultural ease, technological skills, entrepreneurial mindsets, and the ability to manage organizations that are increasingly delayered and disaggregated.

7 One should perhaps now say partners and volunteers, not personnel or (even worse) employees.

8 Rapidly changing lifestyles drive different expectations. Today, staff are more interested in having meaningful and challenging work. They are therefore more loyal to their profession than to the organization. It follows that they are less accommodating of traditional structures and authority and more concerned about work-life balance. Therefore, they are better prepared to take ownership of their careers and development. 
enough. Work also has to make a life."9 Abraham Maslow had, 30 years earlier, conceptualized a theory of human motivation. ${ }^{10}$

\section{Discovering Talent Management}

Talent management refers to the additional processes and opportunities that an organization makes available strategically to a pool of people who are deemed to have talent. If talent is not identified and managed by the entire management team, not only the human resource management unit, talent may just as well be defined as a dormant or untapped quality to be accessed in the future, either in an individual or in the collective.

In point of fact, all organizations are equipped with a talent management system, be it by default or designit is the people side of organizational design, usually entrusted to human resource management units. But a keyword here is "additional": historically, organizations have concerned themselves almost exclusively with top executives, particularly their replacement and succession. (Senior leaders certainly constitute talent even if, more frequently in the public sector, they sometimes owe their jobs to political correctness or tenure. $)^{11}$ Another is "pool": talent management demands that organizations move from

My main job was developing talent. I was a gardener providing water and other nourishment to our top 750 people. Of course, I had to pull out some weeds, too. —Jack Welch replacement and succession planning to cater to the entire talent pool ${ }^{12}$ with other processes and opportunities..$^{13}$ From a richer results chain perspective, talent management is also about recognizing and addressing the constant challenge to have the right people matched to the right jobs at the right time, and doing the right things. That is, talent management is about managing the demand, supply, and flow of talent across the organization through the human capital engine based on organizational strengths, weaknesses, opportunities, and threats. (The Develop-Deploy-Connect model helps generate capability, commitment, and alignment in talent pool segments.) The third related keyword is "strategic": with respect to talent, it intimates that an organization, to maintain a sustainable competitive advantage, may wish to maximize organizational capabilities in certain competencies ${ }^{14}$ and deemphasize others. First, this requires that, having understood what motivates and drives talented people, organizations become management innovators and recognize that they do not need the same talent pool segments all the time (with implications for talent pool strategies, talent management systems, and talent management activities); second, it recognizes at long last that talent management can no longer be the

Peter Drucker. 1973. Management: Tasks, Responsibilities, and Practices. HarperCollins Publishers, Inc.

10 As long ago as 1943, Abraham Maslow (1908-1970), an American psychologist, conceptualized a hierarchy of human needs. People have a basic desire to meet physiological needs, e.g., food, clothing, shelter. Next they seek safety, e.g., personal and financial security, and health and well-being. After physiological and safety requirements are fulfilled, they try to meet social needs, e.g., friendship, intimacy, and family. Next, all humans want to be respected and to have self-esteem and self-respect. Finally, at the top of the pyramid, is what Maslow called "self-actualization," the aspiration to fulfill one's self and become all that one is capable of becoming.

11 Patronage is the control of appointments to jobs or the power to grant other political favors and the distribution of favors, jobs, and offices on a political basis. The word suggests the transgression of real or perceived boundaries of legitimate political influence and the violation of principles of merit and competition in recruitment and promotion. In the international public sector, many governments accept that some political appointments are legitimate and can help fashion a circle of managers sharing a common agenda. However, it is a problem when such appointments permeate systems and undermine merit and competition principles to the cost of organizational performance. Performance suffers when unqualified individuals are recruited or promoted into positions for which they are not suited. More detrimentally, morale is damaged as rank-and-file personnel witness their prospects for advancement based on merit and competition dim inexorably.

12 In any organization, the existing talent pool comprises (i) senior leaders, (ii) those with leadership potential at mid-level, (iii) high performers, (iv) key contributors and technical experts, (v) those in roles critical to delivering the business strategy, (vi) those with skills in short supply and high demand, (vii) the entire workforce, and (viii) those with leadership potential at an entry level. Not surprisingly, given the historical preoccupation with replacement and succession planning, the segments that are viewed as most important to an organization follow the order in which they have just been listed. (Paradoxically, since voluntary resignation at the highest levels is typically low, most organizations do not consider senior leaders a high turnover risk. However, as if to confirm that talent is a critical issue facing organizations today, those with skills in short supply and high demand and high performers usually are, even if little is done about them.) Last but not least, the contents of the talent pools should be reviewed regularly but no finality should be ascribed.

13 This does not mean that organizations should manage the talent in each person, however appealing the idea might be. That notion provides no guidance to determine what resources should be allocated to unearthing (and then perhaps grooming) individual talent.

14 The Knowledge Solutions series couches a set of competencies in terms of strategy development, management techniques, collaboration mechanisms, knowledge sharing and learning, and knowledge capture and storage. 
province of human resource management units; third, it exposes the shortcomings of forced ranking ${ }^{15}$ that many have excoriated as misguided, destructive, and outright antithetical to sound leadership.

Like all new fields, there will be strong returns to research. (Ten years after its birth, confusion or disagreement over

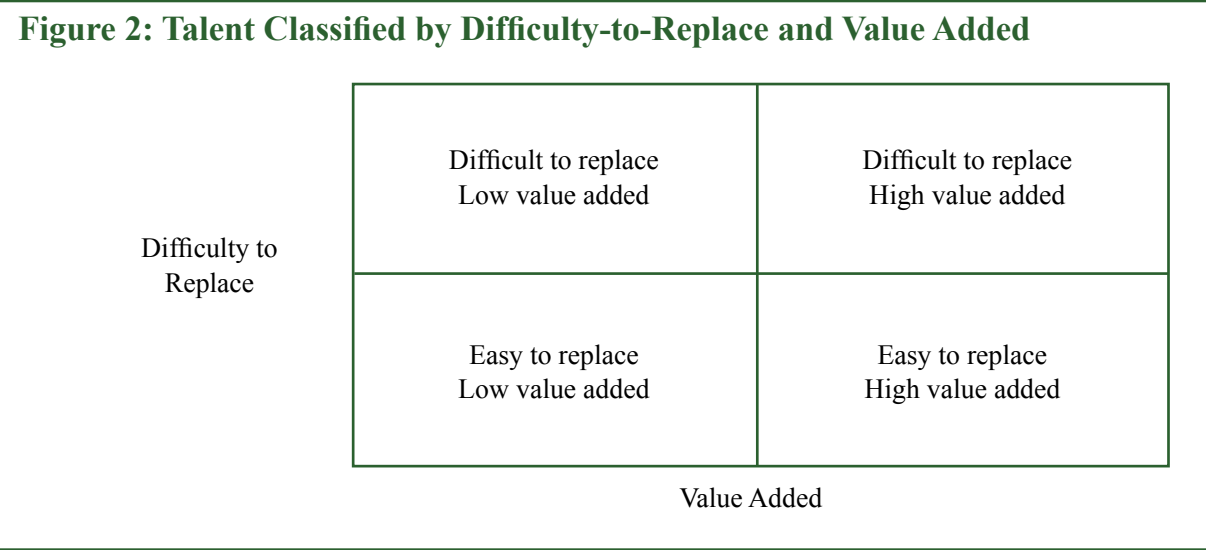

Source: Robert Lewis and Robert Heckman. 2006. Talent Management: A Critical Review. Human Resource Management Review. Vol. 16, no. 2, pp. 139-154. Adapted from Shoshana Zuboff. 1988. In the Age of the Smart Machine: The Future of Work and Power. Basic Books.

the way talent management should be defined, operationalized, or supported are still rife.) Promising areas include the architecture of decisions for talent management ${ }^{16}$ talent pool strategies,${ }^{17}$ and the development of valid and reliable talent management measures. ${ }^{18}$ Notwithstanding, the proactive, strategic nature of talent management opens new vistas. Across the world, it is agreed that human resource management can, indeed should, add more value to organizations. The best way to accomplish this is to become a business partner that directly improves organizational effectiveness. ${ }^{19}$ Any organization needs a wide range of talents to succeed, not only those associated with senior leaders. If an organization recognizes clearly what work needs to be done and what competencies will deliver its strategy for sustainable competitive advantage, knows from talent mapping how best these can be identified and, where current and future gaps are, how they can be closed, numerous methods for managing talent can then be leveraged in support in more open and forward-looking fashion. ${ }^{20}$

15 Forced ranking is a management tool that relies on annual evaluations to locate an organization's best and worst performing personnel, using person-to-person comparisons. To improve the quality of the workforce, managers typically rank personnel against one another into three categories: the top $20 \%$ are " $\mathrm{A}$ " players who are expected to lead the organization in the future; the middle $70 \%$ are " $\mathrm{B}$ " players who are encouraged to improve; the bottom $10 \%$ are " $\mathrm{C}$ " players who are either offered training, encouraged to move elsewhere, or dismissed. Where it works, forced ranking loses its effectiveness after a couple of years because the average quality of personnel increases (else, the exercise is proved a failure) and there are fewer " $\mathrm{C}$ " players to identify. Critics have argued that forced ranking engenders a pseudocompetitive environment conducive to patronage and yes-men; limited risk taking, creativity, and teamwork; as well as unethical (if not cutthroat) behavior that destroys trust in the workplace and depletes morale. It can also discourage workers from asking for help for fear they will be identified as low performers. Ironically, it can result in even good performers being cut if used on a yearly basis.

16 For instance, the initial conditions and decisions that led to the adoption of forced ranking to improve the quality of the workforce are rarely examined. Yet, understanding these is central to interpreting linkages between related human resource management practices and their outcomes.

17 For example, it might be worthwhile to develop systems-level models that illustrate the multi-pool impacts of talent choices in support of a strategy for sustainable competitive advantage.

18 To labor the point, very few organizations bother to assess that forced ranking accurately identifies high performers. Elsewhere, there is no evidence that anything but the most cursory metrics, if any, feed the talent decisions managers make.

19 The times are auspicious: as explained earlier, organizations are more and more dependent on their human capital for their competitive advantage. Since change is a constant, they also need more expertise in change management. Through the talent lens, human resource management can help with change management, influencing strategy and delivering a host of other value-added activities that impact organizational effectiveness.

20 In declining (but not necessarily appropriate) frequency of use, formal methods typically include in-house development programs, coaching and mentoring, succession planning, cross-functional project assignments, high-potential development schemes, graduate development programs, courses at external institutions, internal secondments, assessment centers, 360-degree feedback, job rotation and shadowing, development centers, MBAs, action learning sets, and external secondments. Many of these can, and should, be applied to talent groups, not only individuals. 


\section{"Undefining Talent"}

How talent is defined is specific to an organization. Explanations are highly influenced by markets, industries, organizations, geographies, intellectual disciplines, generations, and of course the nature of talent's work. All are dynamic, and so likely to change over time according to organizational priorities. Rather than accepting universal or prescribed explanations, organizations will find greater value if they formulate their own definitions of what talent and talent management are. It is crucial for the meaning each gives to talent and its management to fit the organization's exogenous and endogenous circumstances and particular needs. A language for talent management activities is a prerequisite to developing a coherent talent management strategy.

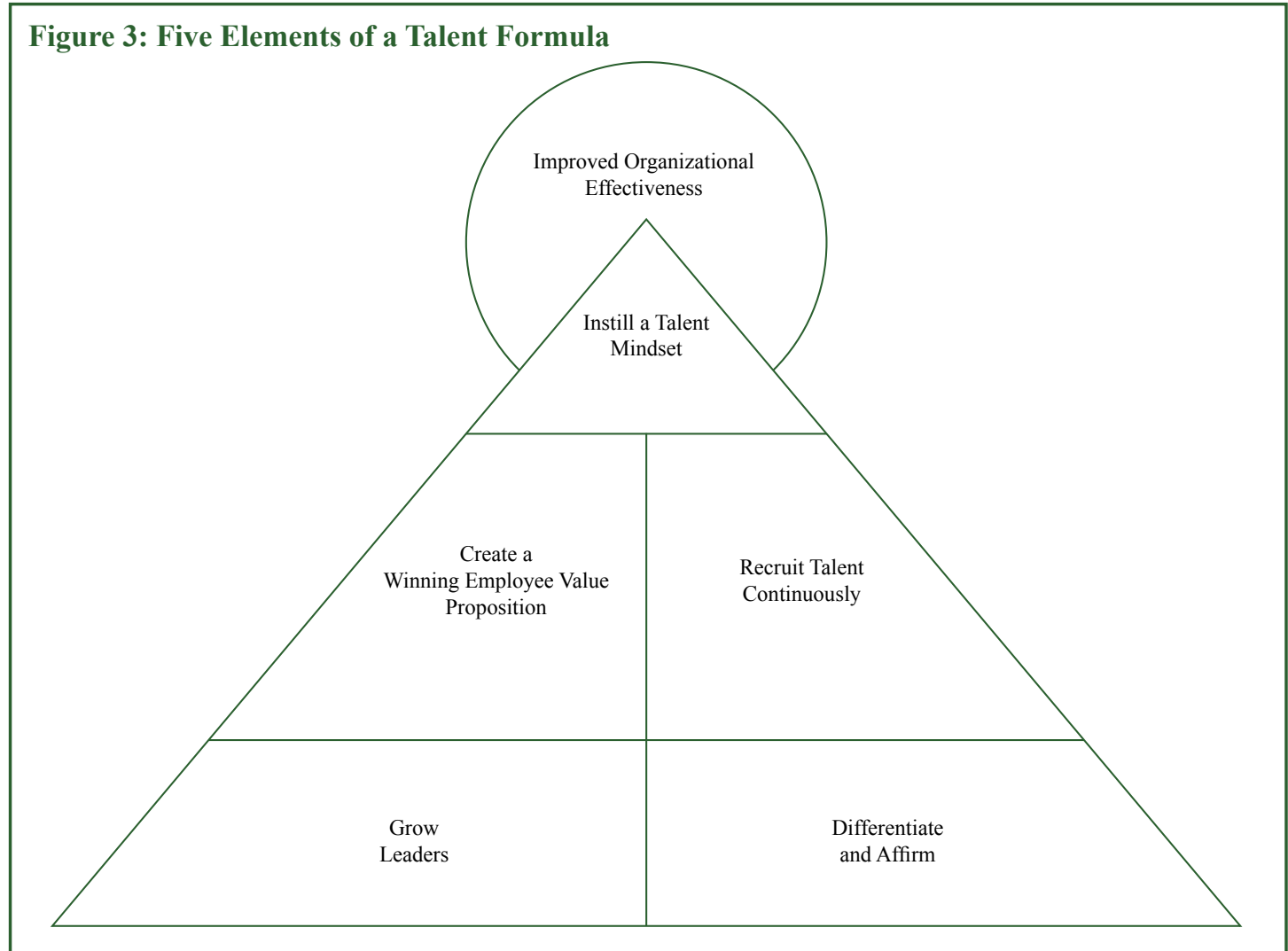

Source: Adapted from Elizabeth Axelrod, Helen Handfield-Jones, and Timothy Welsh. 2001. The War on Talent, Part Two. McKinsey Quarterly. No. 2.

\section{Five Elements of a Talent Formula}

In 2001, McKinsey and Company revisited their earlier study to structure a successful talent formula. Taking care to highlight the differences between the old way and the new, they identified that leading organizations execute against five talent management imperatives to

- Instill a talent mindset at all levels of the organization, beginning with senior leaders.

- Create a winning employee value proposition that brings scarce talent through the doors and keeps it there. The components of the proposition are exciting work, a great organization, wealth and reward, and growth and development.

- Recruit talent continuously.

- Grow leaders.

- Differentiate and affirm. 
Table 1: Thinking about Talent Management

\begin{tabular}{|c|c|c|}
\hline & The Old Way & The New Way \\
\hline Talent Mindset & $\begin{array}{l}\text { Having good people is one of many important } \\
\text { performance levers. } \\
\text { Human resource management is responsible } \\
\text { for people management including recruitment, } \\
\text { compensation, performance reviews, and } \\
\text { succession planning. }\end{array}$ & $\begin{array}{l}\text { Having the right talent throughout the } \\
\text { organization is a critical source of competitive } \\
\text { advantage. } \\
\text { Support for talent management needs to flow } \\
\text { from those at the very top. Every manager is } \\
\text { responsible for attracting, developing, exciting, } \\
\text { and retaining talented people. Every manager } \\
\text { is explicitly accountable for the strength of the } \\
\text { talent pool he or she builds. }\end{array}$ \\
\hline $\begin{array}{l}\text { Employee Value } \\
\text { Proposition }\end{array}$ & $\begin{array}{l}\text { We expect people to pay their dues and work } \\
\text { their way up the line before they get top jobs } \\
\text { and higher salaries. } \\
\text { We have a strong value proposition that attracts } \\
\text { potential employees. }\end{array}$ & $\begin{array}{l}\text { We think of our people as partners and } \\
\text { volunteers and know we have to try to deliver } \\
\text { on their dreams now if we are to keep them. } \\
\text { We have a distinctive employee value } \\
\text { proposition that attracts and retains talented } \\
\text { people. }\end{array}$ \\
\hline Recruiting & $\begin{array}{l}\text { Recruitment is like purchasing; it is about } \\
\text { picking the best from a long line of candidates. }\end{array}$ & $\begin{array}{l}\text { Recruitment is more like marketing and selling; } \\
\text { it is a key responsibility of all managers. }\end{array}$ \\
\hline Growing Leaders & $\begin{array}{l}\text { Development is training. } \\
\text { Development happens when you are fortunate } \\
\text { enough to have a good manager. }\end{array}$ & $\begin{array}{l}\text { Development happens through a series of } \\
\text { challenging job experiences, and candid and } \\
\text { helpful coaching and mentoring. } \\
\text { Development is crucial to performance and } \\
\text { retention and it can be institutionalized. }\end{array}$ \\
\hline $\begin{array}{l}\text { Differentiating } \\
\text { and Affirming }\end{array}$ & - Differentiation undermines teamwork. & $\begin{array}{l}\text { We shower our top performers with } \\
\text { opportunities and recognition. We develop and } \\
\text { nurture mid-performers. We help our lower } \\
\text { performers raise their game or we move them } \\
\text { out or aside. }\end{array}$ \\
\hline
\end{tabular}

Source: Adapted from Elizabeth Axelrod, Helen Handfield-Jones, and Timothy Welsh. 2001. The War on Talent, Part Two. McKinsey Quarterly. No. 2.

\section{Strategic Perspectives}

Given that different organizations aim to achieve different things from their talent management systems, while all seek to achieve some form of talent management, the five elements of a talent formula already look dated. More realistically and usefully, the Chartered Management Institute cautions that strategic perspective shapes the way in which the talent management system is viewed, implemented, and put into operation, such that the same activity can result in a different action or outcome depending on the perspective employed. Crucially, the Chartered Management Institute remarks that an organization may shift its perspective over time in accordance with changes in the organization's strategy for sustainable competitive advantage, and indeed the development and embeddedness of the talent management system itself.

Table 2: Strategic Perspectives on Talent Management

\begin{tabular}{|c|c|c|c|c|c|}
\hline Perspective & Core Belief & $\begin{array}{l}\text { Recruitment } \\
\text { and Selection }\end{array}$ & Retention & $\begin{array}{c}\text { Succession } \\
\text { Planning }\end{array}$ & $\begin{array}{c}\text { Developmental } \\
\text { Approach }\end{array}$ \\
\hline Process & $\begin{array}{l}\text { Include all } \\
\text { processes to } \\
\text { optimize people. }\end{array}$ & $\begin{array}{l}\text { Competence } \\
\text { based, consistent } \\
\text { approach. }\end{array}$ & $\begin{array}{l}\text { Good on } \\
\text { processes such } \\
\text { as work-life } \\
\text { balance and } \\
\text { intrinsic factors } \\
\text { that make people } \\
\text { feel they belong. }\end{array}$ & $\begin{array}{l}\text { Routine review } \\
\text { process based } \\
\text { on performance } \\
\text { review cycle. }\end{array}$ & $\begin{array}{l}\text { Performance } \\
\text { development } \\
\text { plans and } \\
\text { development } \\
\text { reviews as part } \\
\text { of performance } \\
\text { management. } \\
\text { Maybe some } \\
\text { individual } \\
\text { interventions. }\end{array}$ \\
\hline
\end{tabular}




\begin{tabular}{|c|c|c|c|c|c|}
\hline Perspective & Core Belief & $\begin{array}{l}\text { Recruitment } \\
\text { and Selection }\end{array}$ & Retention & $\begin{array}{c}\text { Succession } \\
\text { Planning } \\
\end{array}$ & $\begin{array}{c}\text { Developmental } \\
\text { Approach }\end{array}$ \\
\hline Cultural & $\begin{array}{l}\text { Belief that talent } \\
\text { is needed for } \\
\text { success. }\end{array}$ & $\begin{array}{l}\text { Look for raw } \\
\text { talent. Allow } \\
\text { introductions } \\
\text { from in-house. }\end{array}$ & $\begin{array}{l}\text { Allow people } \\
\text { the freedom to } \\
\text { demonstrate } \\
\text { their talent, and } \\
\text { to succeed and } \\
\text { fail. }\end{array}$ & $\begin{array}{l}\text { Develop } \\
\text { in-house if } \\
\text { possible, if not } \\
\text { look outside. }\end{array}$ & $\begin{array}{l}\text { Individuals } \\
\text { negotiate } \\
\text { their own } \\
\text { development } \\
\text { paths. Coaching } \\
\text { and mentoring } \\
\text { are standard. }\end{array}$ \\
\hline Competitive & $\begin{array}{l}\text { Keep talent } \\
\text { away from the } \\
\text { competition. }\end{array}$ & $\begin{array}{l}\text { Pay the best so } \\
\text { you attract the } \\
\text { best. Poach the } \\
\text { best from the } \\
\text { competition. }\end{array}$ & $\begin{array}{l}\text { Good people } \\
\text { like to work } \\
\text { with good } \\
\text { people. Aim to } \\
\text { be employer of } \\
\text { choice. }\end{array}$ & $\begin{array}{l}\text { Geared toward } \\
\text { retention- } \\
\text { letting people } \\
\text { know what their } \\
\text { target jobs are. }\end{array}$ & $\begin{array}{l}\text { Both } \\
\text { planned and } \\
\text { opportunistic } \\
\text { approaches } \\
\text { adopted. } \\
\text { Coaches and } \\
\text { mentors used to } \\
\text { build loyalty. }\end{array}$ \\
\hline Developmental & $\begin{array}{l}\text { Accelerate the } \\
\text { development of } \\
\text { high potentials. }\end{array}$ & $\begin{array}{l}\text { Ideally only } \\
\text { recruit at entry } \\
\text { point and then } \\
\text { develop. }\end{array}$ & $\begin{array}{l}\text { Clear } \\
\text { development } \\
\text { paths and } \\
\text { schemes to lock } \\
\text { high potentials } \\
\text { into career paths. }\end{array}$ & $\begin{array}{l}\text { Identified } \\
\text { groups will be } \\
\text { developed for } \\
\text { each level of the } \\
\text { organization. }\end{array}$ & $\begin{array}{l}\text { Both } \\
\text { planned and } \\
\text { opportunistic. }\end{array}$ \\
\hline $\begin{array}{l}\text { Human Resource } \\
\text { Planning }\end{array}$ & $\begin{array}{l}\text { Right people in } \\
\text { the right jobs at } \\
\text { the right time. }\end{array}$ & $\begin{array}{l}\text { Target areas of } \\
\text { shortage across } \\
\text { the company. } \\
\text { Numbers and } \\
\text { quotas approach. }\end{array}$ & $\begin{array}{l}\text { Turnover } \\
\text { expected, } \\
\text { monitored, and } \\
\text { accounted for in } \\
\text { plans. }\end{array}$ & $\begin{array}{l}\text { Detailed in- } \\
\text { house mappings } \\
\text { for individuals. }\end{array}$ & $\begin{array}{l}\text { Planned in } \\
\text { cycles according } \\
\text { to business } \\
\text { needs. }\end{array}$ \\
\hline $\begin{array}{l}\text { Change } \\
\text { Management }\end{array}$ & $\begin{array}{l}\text { Use talent } \\
\text { management } \\
\text { to instigate } \\
\text { change in the } \\
\text { organization. }\end{array}$ & $\begin{array}{l}\text { Seek out } \\
\text { mavericks and } \\
\text { change agents } \\
\text { to join the } \\
\text { organization. }\end{array}$ & $\begin{array}{l}\text { Projects and } \\
\text { assignments } \\
\text { keep change } \\
\text { agents, but } \\
\text { turnover of } \\
\text { mainstay staff } \\
\text { can occur. }\end{array}$ & $\begin{array}{l}\text { Can be a bit } \\
\text { opportunistic } \\
\text { initially until } \\
\text { change is } \\
\text { embedded. }\end{array}$ & $\begin{array}{l}\text { Change agents } \\
\text { develop others } \\
\text { who align } \\
\text { with them and } \\
\text { become the next } \\
\text { generation of } \\
\text { talent. }\end{array}$ \\
\hline Area & \multicolumn{5}{|c|}{ Operational Dimension } \\
\hline Defining & \multicolumn{5}{|c|}{$\begin{array}{l}\text { Size of talent pool, entry criteria, decision process, permanency of definition, recruitment as a } \\
\text { source of talent, transparency }\end{array}$} \\
\hline Developing & \multicolumn{5}{|c|}{$\begin{array}{l}\text { Development path, development focus, support, influence on career, connected conversations, } \\
\text { organizational values, risk }\end{array}$} \\
\hline $\begin{array}{l}\text { Structures and } \\
\text { Systems }\end{array}$ & \multicolumn{5}{|c|}{$\begin{array}{l}\text { Performance management, talent management processes, use of technology, systems flexibility, } \\
\text { ownership of talent }\end{array}$} \\
\hline
\end{tabular}

Source: Adapted from Eddie Blass. 2007. Talent Management: Maximizing Talent for Business Performance. Chartered Management Institute.

\section{Toward Integrated Talent Management?}

The value of an integrated model for managing talent that links directly to improved organizational effectiveness is not lost on organizations. However, at this juncture, many note that an integrated approach is one of the most difficult of all talent management activities to implement, sustain, and enhance. ${ }^{21}$ Next in line, in terms of difficulty, is creating more consistency in how talent is identified, developed, and moved throughout the organization. Third is giving senior leaders greater ownership of and accountability for the talent pipeline. Next,

21 See Towers Watson. 2009. Managing Talent in Tough Times: A Tipping Point for Talent Management. 
in diminishing order of difficulty, is focusing more on key workforce segments; redefining the critical attributes and competencies needed for the next generation of leaders; linking rewards more closely to performance; improving quality and use of analytics to monitor the need for, and supply of, talent and better differentiate performance; and scaling and adapting talent strategies on a global basis. Recognizing that these processes are necessary to succeed in the 21 st century is the first, essential step.

\section{Leading Mavericks}

Inevitably, any discussion of talent management brings a focus to bear on mavericks. They are the handful of very clever, willfully independent, and highly creative individuals, often evangelistic believers, who produce remarkable results on their own..$^{22}$ If organizations are finding it difficult to retain top talent, they are finding it almost impossible to maintain productive relationships with mavericks. But mavericks do not necessarily walk away. Contrary to common belief, they need the organization in the same measure that it needs them. (They cannot operate without the systems and resources it makes available.) Managers should be aware of the attributes that mavericks share. (Their one defining characteristic is that they do not want to be "led".) But the art of leading mavericks can be one of the most rewarding skills one

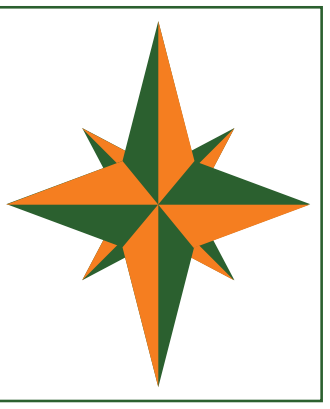
can develop for an organization. A few tips follow:

- Understand the multiple motivations and diverging expectations of mavericks: turn their frustrations into satisfaction by actively enabling their talents to find outlets.

- Do not take mavericks for granted: they do not stand still and it pays to grant them attention with productive talk. ${ }^{23}$

- Inspire talent to stay by being personally courageous.

- Be generous: advertise the talent of mavericks to others.

- Expect that mavericks will outgrow you. and help them to do so.

\section{Further Reading}

ADB. 2008. Managing Knowledge Workers. Manila. Available: www.adb.org/documents/information/ knowledge-solutions/managing-knowledge-workers.pdf

2009a. Growing Managers, Not Bosses. Manila. Available: www.adb.org/documents/information/ knowledge-solutions/growing-managers-not-bosses.pdf

2009b. Harnessing Creativity and Innovation in the Workplace. Manila. Available: www.adb.org/ documents/information/knowledge-solutions/harnessing-creativity-and-innovation-in-the-workplace.pdf Robert Lewis and Robert Heckman. 2006. Talent Management: A Critical Review. Human Resource Management Review. Vol. 16, no. 2, pp. 139-154.

Kaye Thorne and Andy Pellant. 2007. The Essential Guide to Managing Talent: How Top Companies Recruit, Train, and Retain the Best Employees. Kogan Page Limited.

\section{For further information}

Contact Olivier Serrat, Head of the Knowledge Management Center, Regional and Sustainable Development Department, Asian Development Bank (oserrat@adb.org).

22 Mavericks know their self-worth and will not readily offer thanks for help. They are organizationally astute and well connected, which leads them to downplay hierarchy and demand instant access. Their high creativity is the flipside of their low boredom threshold.

23 Kaye Thorne and Andy Pellant have proposed a useful competency-based development plan for talent: (i) generates novel ideas, avoids early conclusions; (ii) identifies and explores wider, less obvious options in a situation; (iii) is intrigued by new concepts and leverages them to gain business advantage; (iv) develops further, implements, and embeds new ideas, processes, or products; (v) takes calculated risks; (vi) offers independent ideas, challenges the status quo; and (vii) turns creative ideas into effective business solutions. See Kaye Thorne and Andy Pellant. 2007. The Essential Guide to Managing Talent: How Top Companies Recruit, Train, and Retain the Best Employees. Kogan Page Limited. 
Asian Development Bank

$A D B$ 's vision is an Asia and Pacific region free of poverty. Its mission is to help its developing member countries reduce poverty and improve the quality of life of their people. Despite the region's many successes, it remains home to two thirds of the world's poor: 1.8 billion people who live on less than $\$ 2$ a day, with 903 million struggling on less than $\$ 1.25$ a day. $A D B$ is committed to reducing poverty through inclusive economic growth, environmentally sustainable growth, and regional integration.

Based in Manila, ADB is owned by 67 members, including 48 from the region. Its main instruments for helping its developing member countries are policy dialogue, loans, equity investments, guarantees, grants, and technical assistance.

Knowledge Solutions are handy, quick reference guides to tools, methods, and approaches that propel development forward and enhance its effects. They are offered as resources to ADB staff. They may also appeal to the development community and people having interest in knowledge and learning.

The views expressed in this publication are those of the author(s) and do not necessarily reflect the views and policies of the Asian Development Bank (ADB) or its Board of Governors or the governments they represent. $A D B$ encourages printing or copying information exclusively for personal and noncommercial use with proper acknowledgment of ADB. Users are restricted from reselling, redistributing, or creating derivative works for commercial purposes without the express, written consent of ADB.

Asian Development Bank

6 ADB Avenue, Mandaluyong City

1550 Metro Manila, Philippines

Tel +6326324444

Fax +6326362444

knowledge@adb.org

www.adb.org/knowledgesolutions 